\title{
Development of monospecific polyclonal antibodies against hypervirulent Klebsiella pneumoniae
}

\author{
DARNIATI $^{1}$, SURACHMI SETIYANINGSIH ${ }^{2, \bullet}$, DEWI RATIH AGUNGPRIYONO ${ }^{3}$, \\ EKOWATI HANDHARYANI \\ ${ }^{1}$ Animal Biomedical Sciences, Department of Veterinary Clinic Reproduction and Pathology, Faculty of Veterinary Medicine, Institut Pertanian Bogor \\ J1. Agatis, Kampus IPB Dramaga, Bogor 16680, West Java, Indonesia \\ ${ }^{2}$ Department of Animal Disease and Public Health, Faculty of Veterinary Medicine, Institut Pertanian Bogor. Jl. Agatis, Kampus IPB Dramaga, Bogor \\ 16680, West Java, Indonesia. Tel.: +62-251-8425503, ^email: surachmi@apps.ipb.ac.id, darni_zain@unsyiah.ac.id \\ ${ }^{3}$ Department of Veterinary Clinic Reproduction and Pathology, Faculty of Veterinary Medicine, Institut Pertanian Bogor. Jl. Agatis, Kampus IPB \\ Dramaga, Bogor 16680, West Java, Indonesia
}

Manuscript received: 25 November 2020. Revision accepted: 10 December 2020.

\begin{abstract}
Darniati, Setiyaningsih S, Agungpriyono DR, Handharyani E. 2021. Development of monospecific polyclonal antibodies against hypervirulent Klebsiella pneumoniae. Biodiversitas 22: 99-105. The aim of the research was to produce monospecific antibodies against Klebsiella pneumoniae serotype K1 and K2. Klebsiella pneumonia isolates were recovered from pneumonic lungs of Aceh cattle. The bacteria were identified by rpoB (RNA polymerase $\beta$ subunit) PCR amplification specific for $K$. pneumoniae. The presence of capsule cluster gene $m a g A$ and $k 2 A$ was used to characterize capsular serotype K1 and K2, respectively. Antisera were produced using serial immunization of New Zealand White rabbits with $K$. pneumoniae serotypes $\mathrm{K} 1$ and $\mathrm{K} 2$. The presence of antibodies was determined by using immunodiffusion test and purification was performed by immunoaffinity purification method. K. pneumoniae antibodies began to appear on the $14^{\text {th }}$ day after the first injection and progressively intensified after the $1^{\text {st }}$ and $2^{\text {nd }}$ booster. The crossreactivity between the antigen was eliminated by absorbing the antisera with the opposite antigen and several serotypes of non-K1/K2. After purification, serum protein concentrations were substantially decreased from $58.48 \mu \mathrm{g} / \mu \mathrm{L}$ and $53.99 \mu \mathrm{g} / \mu \mathrm{L}$ to $2.38 \mu \mathrm{g} / \mu \mathrm{L}$ and $3.72 \mu \mathrm{g} / \mu \mathrm{L}$ for $\mathrm{K} 1$ and $\mathrm{K} 2$, respectively). The SDS-PAGE analysis showed two bands with molecular weight at $54 \mathrm{kDa}$ and $25 \mathrm{kDa}$ representing the heavy and light chains of immunoglobulin $\mathrm{G}$, respectively. Purified polyclonal antiseras against K. pneumoniae serotypes $\mathrm{K} 1$ and $\mathrm{K} 2$ showed high affinity and specificity for homologous antigens in immunodiffusion and direct agglutination tests, and immunohistochemical staining.
\end{abstract}

Keywords: Immunoaffinity purification, immunoglobulin, Klebsiella pneumoniae, monospecific, SDS-PAGE

Abbreviations: AGID: Agar Gel Immunodoffusion test, CPS: Capsule polysaccharide, hvKp: Hypervirulent K. pneumoniae, IgG: immunoglobulin G, IHC: Immunohistochemical staining, rpoB: RNA polymerase $\beta$ subunit, SDS-PAGE: Sodium dodecyl sulfatepolyacrylamide gel electrophoresis

\section{INTRODUCTION}

Klebsiella pneumoniae is an opportunistic pathogen found in the environment (surface waters, vegetation, and soil) (Martin and Bachman 2018; Priyanka et al. 2020). K. pneumoniae was considered to be one of the most important zoonotic bacterial pathogens, and induced serious infection mainly due to hypervirulent $K$. pneumoniae (hvKp) strains (Jun 2018; Effah et al. 2020). The hvKp infections have been associated with severe suppurative pneumonia in sheep and sea lion (Gameel et al. 1991; Jang et al. 2010), and widely reported as the causative agent of mastitis in cattle with a poor prognosis (Ribeiro et al. 2008). Pulmonary infections in cattle caused by $K$. pneumoniae infection are very limited, primarily in Indonesian local cattle.

Klebsiella pneumoniae has a number of virulence factors, including capsules, endotoxins, siderophores, ironscavenging systems, and adhesins (Remya et al. 2019). The capsule polysaccharide (CPS) is the important virulence factor in $K$. pneumoniae that mediated antibiotic resistance and immune evasion strategies. The hvKp strains produce thick CPS (hypermucoviscous) and the majority of isolates belong to serotype K1 and K2 (Yeh et al. 2007; Siu et al. 2012; M'lan-Britoh et al. 2017; Remya et al. 2019; Lin et al. 2020). High mortality rates occur in most infections with hvKp due to resistance against various available antibiotics, making them difficult to treat and control (Opoku-Temeng et al. 2019; Li et al. 2019).

Early diagnosis is crucial for disease control. In clinical practice, the diagnosis of disease is carried out through observation of clinical symptoms, histopathological lesions, and laboratory examinations. Immunodiagnostic tests are beneficial to confirm a diagnosis more quickly and with certainty (Patterson et al. 2002). Recently, mammalian serum has been widely used for diagnostic and therapeutic purposes (Ascoli and Aggeler 2018). Rabbit polyclonal antibodies were commonly used in various tests, such as immunohistochemical staining, enzyme-linked immunosorbent assay (ELISA), double diffusion, radial immunodiffusion, western blot, and radioimmunoassay (Sorden et al. 1999; Majidi and Amirkhiz 2007; Sadeghi et 
al. 2018). In addition, polyclonal antibodies have been used and show a lot of advantages because they are able to bind to multi-epitope antigens. The binding of antibodies to various epitopes allows polyclonal antibodies to bind to specific antigens in various tests making them more effective in detecting target antigens (Weber et al. 2017).

However, some properties of antibodies, such as sensitivity, cross-reactivity and specificity, are important to improve the accuracy of the assay (Pohanka 2009). In this research, we developed polyclonal antibodies monospecific anti-K. pneumoniae serotypes $\mathrm{K} 1$ and $\mathrm{K} 2$ in the rabbits. The results of the study provide a new reagent candidate for developing diagnostic kit for detecting K. pneumoniae during the early stages of infection.

\section{MATERIALS AND METHODS}

\section{Ethical approval}

All animal experiments and procedures were approved by the Animal Care and Use Committee of Research and Community Services Institution, IPB University, with approval number: 144/KEH/SKE/VII/2019.

\section{Bacterial isolate}

Klebsiella pneumoniae serotypes $\mathrm{K} 1$ and $\mathrm{K} 2$ were isolated from infected lungs of Aceh cattle. Identification of suspected colonies was done by detecting $r p o B$ (RNA polymerase $\beta$ subunit) through Polymerase Chain Reaction (PCR) amplification specific for $K$. pneumoniae. Multiplex PCR was performed using PCR Kit $\left(\mathrm{MyTaq}^{\mathrm{TM}}\right.$ Red Mix, Bioline) and specific primers to target magA (serotype K1) and $k 2 A$ (serotype K2) genes.

\section{Animal}

Four New Zealand white breed rabbits with 10-16 months old and 2500-3000 $\mathrm{g}$ in weight at the time of the study were used in the present study. The study was carried out at the rabbit facilities housed individually in galvanized wire cages. Each rabbit was fed $120 \mathrm{~g}$ of a commercial rabbit diet (Vital Rabbit ${ }^{\circledR}, 15 \%$ protein). In addition, the rabbits received multi-vitamin supplements daily. All animals were adapted in the rabbit facilities for a week before the study. The animals were sedated with ketaminexylazine $(30 / 5 \mathrm{mg} / \mathrm{kg} \mathrm{BB})$ and saline mixture administered by intramuscular route before all procedures and exams.

\section{Preparation of antigen}

Heat-killed $K$. pneumoniae serotypes $\mathrm{K} 1$ and $\mathrm{K} 2$ isolates were used to induce the production of antibodies. Overnight cultured bacteria were transferred to fresh Brain Heart Infusion broth (BHIB) medium and incubated to early exponential phase of growth. Subsequently, bacteria were harvested by centrifugation $(10000 \times \mathrm{g}$ for $10 \mathrm{~min})$, three times with phosphate buffer saline (PBS pH 7.2) to eliminate extracellular product. The cell pellets obtained were equalized to Mc Farland 2 concentration $\left(1.5 \times 10^{8}\right)$ and inactivated in waterbath for 30 minutes at $100^{\circ} \mathrm{C}$. The bacterial suspension was emulsified in the Freund's complete adjuvant (FCA) with 1: $1(\mathrm{v} / \mathrm{v})$ in ratio.

\section{Production of antibody}

All rabbits were used and tested for the presence of anti-K. pneumoniae antibodies prior to immunization. Each two rabbits were given two subcutaneous injections with 1 mL FCA bacterial emulsion of each serotype at two weeks interval. Two weeks later, an intravenous injection was carried out with $0.5 \mathrm{~mL}$ of bacterial suspension without adjuvant.

To monitor the induction of specific antibody response, blood was collected four times at one week interval started two weeks after initial injection. Total bleeding was performed on day- 9 after the last injection. The blood was stored at room temperature $\left( \pm 25^{\circ} \mathrm{C}\right)$ for an hour and continued with storage at $4^{\circ} \mathrm{C}$ overnight. The serum was separated by aspiration and centrifugation at $2500 \mathrm{rpm}$ for 15 minutes. Furthermore, serum was heat inactivated at $56^{\circ} \mathrm{C}$ for 30 minutes and $0.1 \%$ sodium azide was added to maintain stability during storage. Serum was aliquoted in a $1.5 \mathrm{~mL}$ tube and stored at $-20^{\circ} \mathrm{C}$ until use. The presence of specific antibodies against each serotype was analyzed by agar gel immunodiffusion Test (AGID).

\section{Immunodifusion assay}

Agar gel immunodiffusion test (AGID) was performed to determine immunoreactivity of the antibodies by using the method described by Hornbeck (2017) with minor modification. Immunodiffusion slide was prepared by pouring $5 \mathrm{~mL}$ of $1 \%$ agarose in phosphate buffered saline containing $0.05 \%$ Na azide (PBSN) and 2\% PEG 6000. Gel puncher was used to produce $4 \mathrm{~mm}$ well in and $4 \mathrm{~mm}$ interspace. The peripheral wells were filled with the antigens, while the center well was filled with the serum. The slide were incubated at $37^{\circ} \mathrm{C}$ and read at 24,48 , and 72 $\mathrm{h}$ under diffused light. Serum samples showed a line of precipitation between the wells of serum and antigens were considered positive.

\section{Antibody purification}

Antibody purification was carried out by immunoaffinity purification method. The purification process was performed in 2 steps, (1) absorption of antibodies with opposite antigen, followed by absorption with serotypes non K1/K2 respectively; (2) absorption with homologous antigen and elution of specific antibodies. The antigens for absorption were prepared according to a previously described technique with modifications (Hellman et al. 1997). Bacterial culture in log phase were harvested from agar plate, suspended in phosphate buffer saline (PBS) and washed by centrifugation at $5000 \mathrm{~g}$ for 8 minutes. After the second centrifugation, the cells pellet was heated for 1 hour in water bath at a temperature of 96$100^{\circ} \mathrm{C}$. Samples were then resuspended in PBS and washed three times. First step of absorption was done by resuspending the pellet into opposite rabbit serum \pm 10 $\mu \mathrm{g} / \mathrm{mL}$ ( $\mathrm{K} 1$ antigens to $\mathrm{K} 2$ serum; $\mathrm{K} 1$ antigens to $\mathrm{K} 2$ serum). The mixture was incubated at $37^{\circ} \mathrm{C}$ for $2 \mathrm{~h}$ and followed by incubation at $4^{\circ} \mathrm{C}$ overnight. The supernatant was collected after centrifugation for 30 minutes at $6000 \mathrm{~g}$ and used in the absorption with non-K1/K2 bacteria using the same procedure. 
In the second step, the cell pellet of $\mathrm{K} 1$ and $\mathrm{K} 2$ antigen was resuspended in homologous serum or supernatant from first step. An antigen-antibody complex was collected by centrifugation after overnight incubation. The specific antibody was collected by adding Ig $G$ elution buffer (Thermo Scientific $^{\mathrm{TM}}$ Pierce $^{\mathrm{TM}} \mathrm{IgG}$, USA) into pellets and incubated for 10 minutes. The suspension was transferred into column and centrifuged at a rate of $\geq 16000 \mathrm{~g}$. The supernatant (monospecific antibody) was neutralized with tris buffer $(1 \mathrm{M}, \mathrm{pH} 8)$ immediately. The monospecific antibody characterization was examined by sodium dodecyl sulfate-polyacrylamide gel electrophoresis (SDS-PAGE) method.

\section{Protein gel electrophoresis}

Purified antibody was analyzed by sodium dodecyl sulfate-polyacrylamide gel electrophoresis (SDS-PAGE) method using horizontal electrophoresis method (Amersham ECL gel box, GE 17 Healthcare), with 12\% polyacrylamide concentration for separating gel and $4 \%$ for stacking gel. Sample was dissolved in $2 \times$ sample buffer (2.5 mL 0.5M Tris pH 6.8; $2.0 \mathrm{~mL}$ glycerol; $4.0 \mathrm{~mL} 10 \%$ SDS; $0.2 \mathrm{~mL}$ 2-mercaptoethanol; $0.2 \mathrm{~mL}$ bromophenol blue (1.0\%); and $3.2 \mathrm{~mL}$ distilled water), and then heated at $60^{\circ} \mathrm{C}$ for 5 minutes. Sample suspension was heated for 5 minutes at $90-100^{\circ} \mathrm{C}$, and a total of $10 \mu \mathrm{l}$ antibody samples and $5 \mu$ protein markers (PM2700 ExcelBand ${ }^{\mathrm{TM}}$ 3-color Broad Range Protein Marker, SMOBIO Technology, Inc., Taiwan) were filled into each well. Protein separation was performed by electrophoresis with a voltage of $160 \mathrm{~V}$ for 60 minutes. The gel was then removed from the cassette and stained with coomassie solution $(40.0 \%$ methanol; $10.0 \%$ acetic glacial; and $0.1 \%$ blue coomassie). The stain was stopped by destaining solution $(40.0 \%$ methanol and $10.0 \%$ acetic glacial).

\section{Monospecificity of antibodies \\ Direct agglutination test}

Direct agglutination assay was performed according to the test procedure described by Sarba et al. (2020). The serum and the reagent (safranin stained $K$. pneumoniae antigens) were brought to room temperature $\left(22 \pm 5^{\circ} \mathrm{C}\right)$ before use. Fifty microliters of the reagent and equal volume of the serum were gently mixed on a sterile slide by rotating for about 2-3 minutes. Any degree of agglutination was taken as evidence of seropositivity.

\section{Immunohistochemical staining}

Tissue section that has been attached on a microscopic slide using poly-L-lysine (1\%) was deparaffinized, rehydrated with distilled water and put under flowing with tap water for 5 minutes, then followed by phosphatebuffered saline (PBS) Tween. The method followed the protocol that was supplied with the mouse and rabbit specific HRP/DAB (ABC) detection IHC kit (Abcam, ab64264 ${ }^{\circledR}$ ). Blocking endogenous activity was performed with immersion in $3 \% \quad \mathrm{H}_{2} \mathrm{O}_{2}$ at room temperature for 10 minutes. Blocking nonspecific protein binding used $10 \%$ normal goat serum in room temperature for 10 minutes. Tissue section was incubated overnight at $4^{\circ} \mathrm{C}$ with primary antibody rabbit anti-K. pneumoniae polyclonal antibody, and followed by incubation with secondary antibody Dako REAL ${ }^{\mathrm{TM}}$ envision ${ }^{\mathrm{TM}} / \mathrm{HRP}$, rabbit/mouse (ENV) for 30 minutes. The streptavidin-HRP was applied for 30 minutes at room temperature. The section was visualized using Dako REALTM DAB+chromogen in Dako REALTM substrate buffer (K5007). Finally, the section was counterstained with Mayer's hematoxylin and mounted with Aquamount (BDH Ltd, Poole, UK).

\section{RESULTS AND DISCUSSION}

\section{Bacterial identification}

Polymerase chain reaction was performed to detect 108 bp band rpoB (RNA polymerase $\beta$ subunit) (Figure 1). The $r p o \mathrm{~B}$ gene, has been used as a diagnostic tool for precise bacterial identification and as a locus for phylogenetic analysis (Alves et al. 2006; Chander et al. 2011; He et al. 2016). PCR has been used to identify $K$. pneumoniae capsular serotypes both of $1.283 \mathrm{bp}$ in magA gene and $531 \mathrm{bp}$ in $k 2 A$ gene (Figure 2 ). The magA gene is associated to $\mathrm{K} 1$ serotype, whereas $k 2 A$ is associated to $\mathrm{K} 2$ serotype (Al-Jailawi et al. 2014). Molecular amplification showed that magA was conserved gene among $K$. pneumoniae serotype $\mathrm{K} 1$ and associated to the hypermucoviscous phenotype (Chuang et al. 2006). On the other hand, the $k 2 A$ gene is a capsular genetic determinant specific to which is also a hypervirulent serotype and implicated in liver abscess with endogenous endophthalmitis (Doud et al. 2009; Seo et al. 2016).

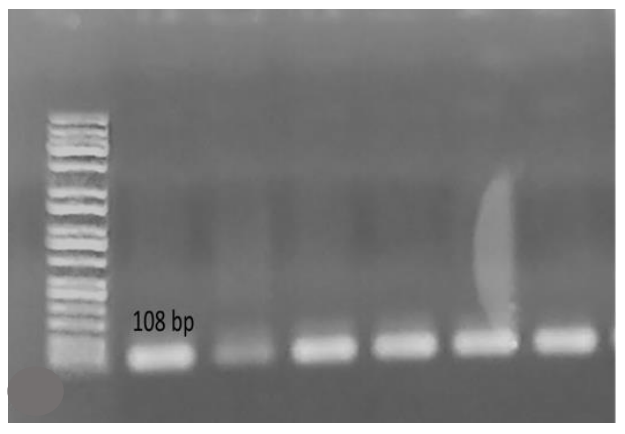

Figure 1. Amplification $r p o B$ gene (108 bp)

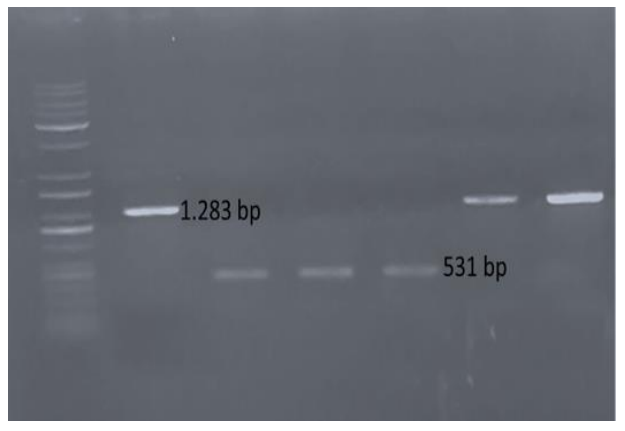

Figure 2. Amplification of $m a g A$ gene (1.283) line 2, 6, 7 and k2A line $3,4,5$ 


\section{Immunoreactivity of antibodies}

Polyclonal antibodies (pAB) are antibodies that have a complex mixture of antibodies with different specificity, affinity, and display multi-epitope binding properties. The presence of rabbit antibodies against $K$. pneumoniae in AGID was detected in the $2^{\text {nd }}$ week after first immunization, and progressively increasing after the $1^{\text {st }}$ and $2^{\text {nd }}$ booster. Strong reaction of antigen-antibody was showed by thick precipitin lines before 24 hours (Figure 3). The high level of antibody production occurred after the second boost via intravenous route. The first immunization and booster were considered to differentiate of memory B and $\mathrm{T}$ cells. Antigens were released from the injection site and reached the marginal zone of the spleen/nodes, an area that is equipped by macrophages, through the bloodstream (Awate et al. 2013; Bronte and Pittet 2013). Memory T cells formed several weeks after the first immunization. Memory cells confer immediate protection and generate secondary responses that are more rapid and a higher degree than primary responses (Sallusto et al. 2010). Secondary responses were mediated by memory B cells that rapidly proliferate and differentiate in response to antigenic stimulation generating a burst of plasma cells and a marked but transient elevation in serum antibodies (Whitton et al. 2004). Furthermore, the $3^{\text {rd }}$ secondary responses were mediated by memory $\mathrm{B}$ cells that rapidly proliferate and differentiate in response to antigenic stimulation generating a burst of plasma cells and a marked but transient elevation in serum antibodies (Nutt et al. 2015; Nandin et al. 2017).

\section{Antibody purification}

Antibodies contain various components of proteins, such as transferrin and albumin (Zhang et al. 2015). Hence, the antibody has to be purified from other parts in serum before characterization. Separation of antibodies can be achieved by using several purification methods, such as absorption of antibodies (Hellman et al. 1997), precipitation of protein with ammonium sulfate (Wingfield, 1998), purification with a protein A (Hober et al. 2007), and immunoaffinity chromatography (Liu et al. 2017).

In the present study, antibody purification was performed using immunoaffinity purification. The antibody passed through two-step absorption against heterologous and homologous antigens to generate monospecific antibody. First step was done with opposite and/or heterologous antigens to eliminate cross-reactivity between several serotypes. Based on AGID, antibody to each serotypes $\mathrm{K} 1$ and $\mathrm{K} 2$ showed cross-reaction lines before heterologous absorption (Figure 4), which could be mediated by O-polysaccharide (O-PS) antigens. Although, there are more than 90 capsular polysaccharides $(\mathrm{K})$ antigens have been identified, $K$. pneumoniae shows limited variability of O-antigens (O1-O9) and consequently the immune system can bind to the surface of various $K$. pneumoniae strains expressing the similar O-antigens subtypes (Guachalla et al. 2017). Absorption of antibodies with opposite antigens (K1 and $\mathrm{K} 2$ ), and several isolates non-K1/K2 can remove nonspecific antibodies against several serotypes of $K$. pneumoniae. Cross absorption is a powerful method used to minimize cross reactions. Serum cross-absorption process can remove antibodies that recognize bacterial surface antigens and produce monospecific antibodies (Zhang et al. 2011).

The second stage of purification was carried out to increase the antibodies specificity. Purification of antibodies with homologous bacteria allowed for antibodies to bind to specific epitope on the surface of an antigen (Hellman et al. 1997). The interaction of antigen and antibody on the AGID slides showed clear precipitation lines without cross-reaction lines between the tested antigens (Figure 5). However, the line of precipitation formed was thinner than the precipitation line before purification. This reduction occurred due to the loss of nonspecific antibody components during the purification process. Purification of antibodies by absorption could decrease the titer of antibodies and increase antibody specificity (Snider 2000; Zhou et al. 2008; Dong et al. 2015). Previous research reported that antibodies purified by immunoaffinity showed higher sensitivity compare to antibodies purified by protein $\mathrm{A}$ or ammonium sulfate precipitation in the enzyme-linked immunosorbent assay (ELISA) (Liu et al. 2017).

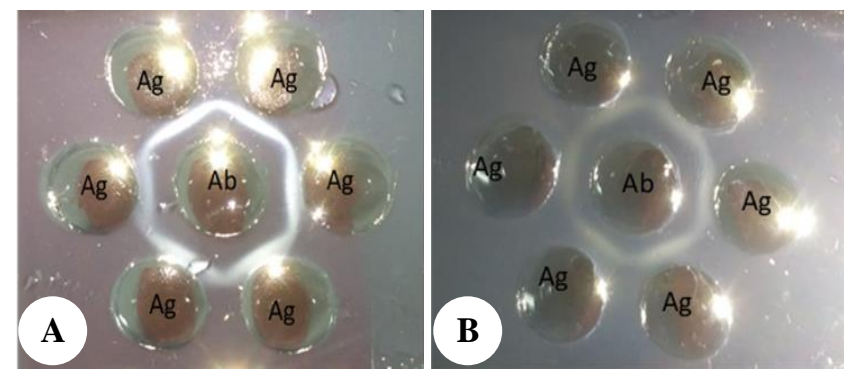

Figure 3. Immunoreactivity of antigen-antibody $K$. pneumoniae showed the precipitation lines of antigen-antibody serotype K1 (A) and K2 (B)

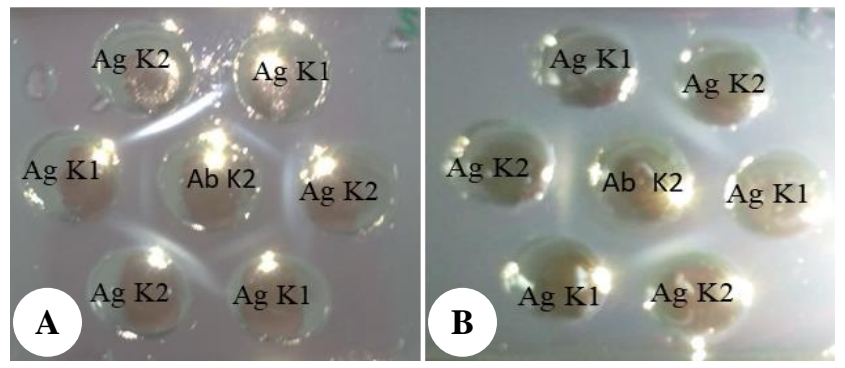

Figure 4. Cross reaction of antigen-antibody $K$. pneumoniae serotype $\mathrm{K} 1$ and $\mathrm{K} 2$ before (A) and after cross absorption (B)

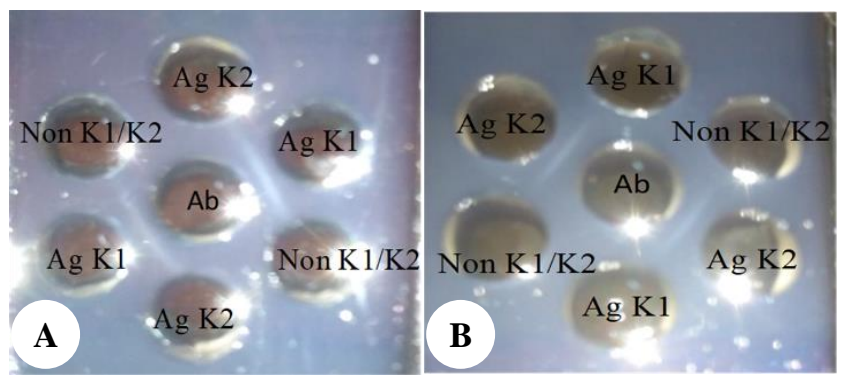

Figure 5. Sensitivity and specificity of antibodies after purification to homolog and heterolog K. pneumoniae serotype K1 (A) and K2 (B) 


\section{Antibody characterization with polyacrylamide gel (SDS PAGE)}

The total protein concentration, before and after purification was determined using the NanoDrop 2000c Spectrophotometer. The techniques enable the assessment of protein concentrations with minimal consumption of sample (Desjardins et al. 2010). The absorbance of serum samples from two groups of rabbits was are shown in Table 1. The total protein concentrations showed significant decrease in protein concentration after purification. A large amount of nonspecific protein was lost during the purification process.

The purity of the rabbit polyclonal anti-K. pneumoniae serotypes $\mathrm{K} 1$ and $\mathrm{K} 2$ was verified by the SDS-PAGE analysis. The molecular weight (MW) of a serum protein can be sodium dodecyl sulfate separated on SDS-PAGE (Matsumoto et al. 2019). Antibodies typically consist of two identical light chains of approximately $25 \mathrm{kDa}$ and two identical heavy chains of approximately $55 \mathrm{kDa}$ (Schroeder Jr and Cavacini 2010; Rodrigo et al. 2015; Weber et al. 2017; Sadeghi et al. 2018). The high molecular weight in heavy chains causes slower migration through the gel compare to light chains which contain a lower molecular weight (Talib et al. 2018). The analysis of SDS-PAGE from purified polyclonal antibody showed two bands with approximate molecular weight at $54 \mathrm{kDa}$ and $25 \mathrm{kDa}$ representing the heavy chain and light chain of the produced antibody respectively (Figure 6).

\section{Monospecificity determination of antibodies}

The monospecificity of the antibodies was demonstrated using direct agglutination test against $K$. pneumoniae serotype $\mathrm{K} 1, \mathrm{~K} 2$, non-K1/K2 and $P$. multocida antigens, and immunohistochemical staining (IHC) on pneumonic lung tissues of Aceh cattle infected with $K$. pneumoniae serotype $\mathrm{K} 1$ or $\mathrm{K} 2$. Based on direct agglutination, monospecific antibodies have the capability to bind to the antigens directly and formed agglutinated aggregates (Figure 7). Strong signal intensity appeared on direct agglutination test and visible in less than 1 minutes. Direct agglutination test can be used as an indicator of the presence of antibodies against bacteria. In addition, this method might be appropriate to be used as an of $K$. pneumoniae antigens and/or antibodies and utilized in disease surveillance/clinical laboratories for rapid identification of pathogens (Danielsson and Kronvall, 1974; Parija and Biswas 2011).

Furthermore, the immunohistochemical examination showed immunopositive distribution in the infected tissue (Figure 8). This result indicated the high sensitivity and specificity of the antibodies. The antibodies could bind to the whole or debris antigens in the tissues. The presence of $K$. pneumoniae antigen was detected in all lung tissues suspected to be infected with $K$. pneumoniae. These findings are consistent with phenotypic identification and molecular detection by polymerase chain reaction (data not shown). Specific immunoperoxidase labeling associated with $K$. pneumoniae serotype K1 was found most frequently within alveolar and bronchiole cells, while antigens of $K$. pneumoniae serotype $\mathrm{K} 2$ were predominantly present in interstitial tissue. Macrophages and lung pneumocytescontains non-capsulated or disrupted bacteria. IHC assay works on specific antigen-antibody reactions, this assay has advantages over traditional staining techniques using enzymes to identify small amounts of protein, enzymes, and tissue structures. The use of monoclonal and polyclonal antibodies to detect specific antigens on tissue parts is an important application of both monoclonal and polyclonal antibodies to determine the presence of antigens in tissue (Duraiyan et al. 2012).

Table 1. Evaluation of protein concentration in the serum of rabbits immunized by $K$. pneumoniae serotype $\mathrm{K} 1$ and $\mathrm{K} 2$

\begin{tabular}{lcc}
\hline \multirow{2}{*}{ Serum samples } & \multicolumn{2}{c}{ Concentration $\left(\boldsymbol{\mu g} \boldsymbol{\mu \mathbf { L } ^ { - 1 } )}\right.$} \\
\cline { 2 - 3 } & Group 1 & Group 2 \\
(Serotype K1) & (Serotype K2) \\
\hline Before purification & 58.48 & 53.99 \\
After purification & 2.38 & 3.72 \\
\hline
\end{tabular}

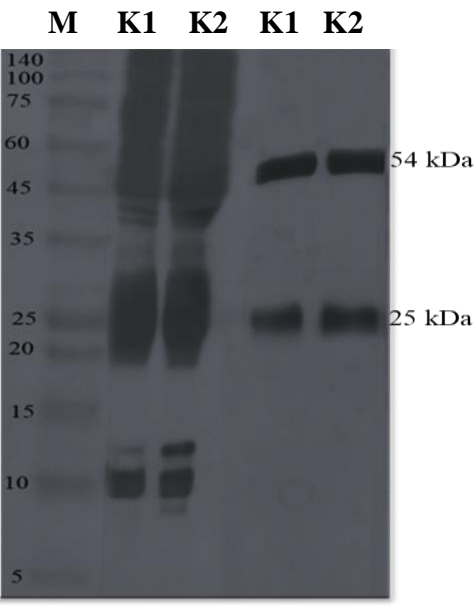

Figure 6. Antibody profile on SDS PAGE. Antibodies against $K$. pneumoniae serotype K1 and K2 (line 2, 3: before purification, and line 4, 5: after purification). M: Marker

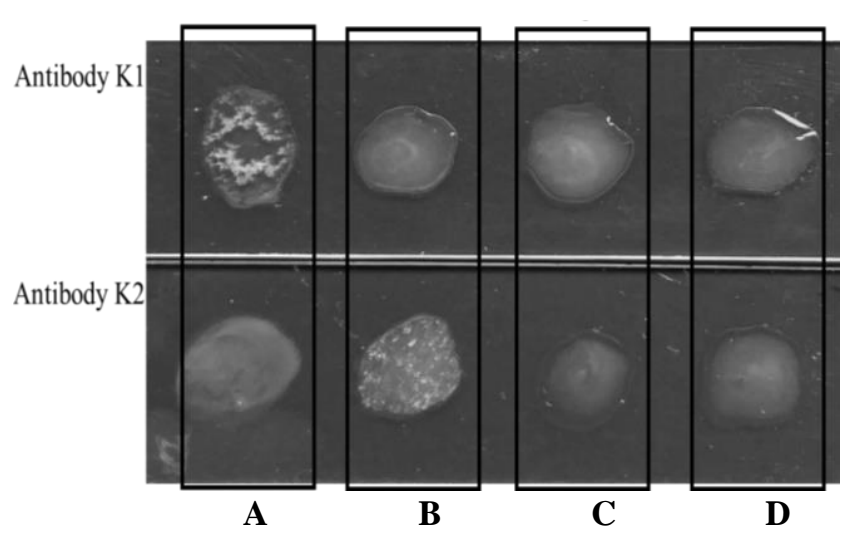

Figure 7. Agglutination test showed monospecificity of antibodies $\mathrm{K} 1$ and $\mathrm{K} 2$ against $K$. pneumoniae serotype K1 (A), K2 (B), non-K1/K2 (C) and P. multocida (D) antigens 


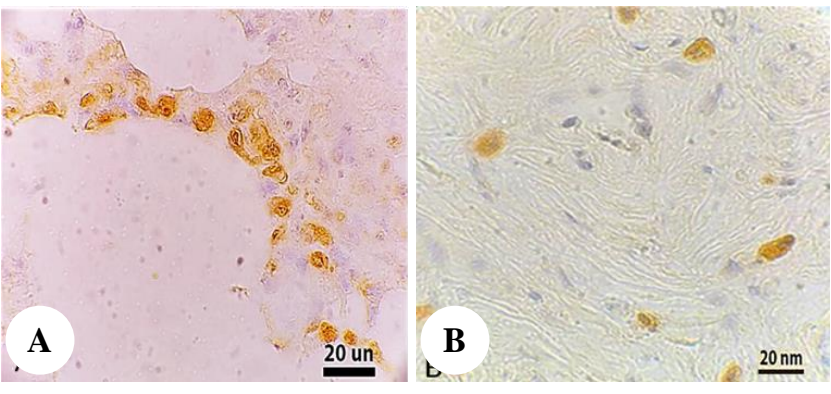

Figure 8. Immunohistochemical staining showed immunoreactive distributions of antigen $K$. pneumoniae serotype K1 (A) and K2 (B) in the pneumonic lungs of Aceh cattle

In conclusion, our study succeeded in producing antibody of anti-K. pneumoniae serotype $\mathrm{K} 1$ andKk 2 in rabbits. The antibodies can be produced within 37 days and the peak concentration of antibody appeared after the third injection via intravenous route. The purified antibody showed two bands estimated at $54 \mathrm{kDa}$ and $25 \mathrm{kDa}$ representing the heavy and light chain of $\mathrm{IgG}$, respectively. These antibodies can be used as a reagent to develop rapid immunodiagnostic test tool for rapid diagnosis of hypervirulent $K$. pneumoniae infection based on the immunodiffusion, direct agglutination, and immunohistochemical assays.

\section{ACKNOWLEDGEMENTS}

This research was supported and funded by the Directorate General of Higher Education of the Republic of Indonesia (DIKTI) with Doctor's dissertation research (No. 4085/IT3.L1/PN/2020). The authors would like to thank the Faculty of Veterinary Medicine, IPB University, Bogor, Indonesia, and Faculty of Veterinary Medicine, Syiah Kuala University, Banda Aceh, Indonesia, for all of their supports during this study.

\section{REFERENCES}

Al-Jailawi MH, Zedan TH, Jassim KA. 2014. Multiplex-PCR assay for identification of Klebsiella pneumoniae. Intl J Pharm Sci Rev Res 26: 112-117.

Alves MS, Da Silva Dias RC, De Castro ACD, Riley LW, Moreira BM. 2006. Identification of clinical isolates of indole-positive and indolenegative Klebsiella spp. J Clin Microbiol 44: 3640-3646. DOI: 10.1128/JCM.00940-06.

Ascoli CA, Aggeler B. 2018. Overlooked benefits of using polyclonal antibodies. BioTechniques 65: 127-136. DOI: 10.2144/BTN-2018 0065 .

Awate S, Babiuk LA, Mutwiri G. 2013. Mechanisms of action of adjuvants. Front Immunol 4: 1-10. DOI: 10.3389/fimmu.2013.00114.

Bronte V, Pittet MJ. 2013. The spleen in local and systemic regulation of immunity. Immunity 39: 806-818. DOI 10.1016/j.immuni.2013.10.010

Chander Y, Ramakrishnan MA, Jindal N, Hanson K, Goyal SM. 2011. Differentiation of Klebsiella pneumoniae and K. oxytoca by multiplex polymerase chain reaction. Int J Appl Res Vet Med 9: 138.

Chuang Y, Fang C, Lai S, Chang S, Wang J. 2006. Genetic determinant of capsular serotype $\mathrm{K} 1$ of Klebsiella pneumoniae causing primary pyogenic liver abscess. J Infect Dis 193: 645-654. DOI: $10.1086 / 499968$.

Danielsson D, Kronvall G. 1974. Slide agglutination method for the serological identification of Neisseria gonorrhoeae with antigonococcal antibodies adsorbed to protein A-containing Staphylococci. Appl Microbiol 27: 368-374.

Desjardins P, Hansen JB, Allen M. 2010 Microvolume protein concentration determination using the NanoDrop 2000c Spectrophotometer. J Vis Exp 33: 1-4. DOI: 10.3791/1610.

Dong D, Liu W, Li H, Wang Y, Li X, Zou D, Yang Z, Huang S, Zhou D, Huang L, Yuan J. 2015. Survey and rapid detection of Klebsiella pneumoniae in clinical samples targeting the $r \operatorname{cs} A$ gene in Beijing, China. Front Microbiol 6: 1-6. DOI: 10.3389/fmicb.2015.00519

Doud MS, Grimes-Zeppegno R, Molina E, Miller N, Balachandar D, Schneper L, Poppiti R, Mathe K. 2009. A k2A-positive Klebsiella pneumoniae causes liver and brain abscess in a Saint Kitt's man. Int $\mathbf{J}$ Med Sci 6: 301-304. DOI: 10.7150/ijms.6.301.

Duraiyan J, Govindarajan R, Kaliyapan K, Palanisamy M. 2012. Applications of immunohistochemistry. J Pharm Bioallied Sci 4: S307-S309. DOI: 10.4103/0975-7406.100281.

Effah CY, Sun T, Liu S, Wu Y. 2020. Klebsiella pneumoniae: An increasing threat to public health. Ann Clin Microbiol Antimicrob 19 (1): 1. DOI: $10.1186 / \mathrm{s} 12941-019-0343-8$.

Gameel AA, El Sanousi SM, Al Nawawi F, Al Shazly MO. 1991. Association of Klebsiella organisms with pulmonary lesions in sheep. Revue d'élevage et de Médecine Vétérinaire Des Pays Tropicaux 44: 161-164.

Guachalla LM, Stojkovic K, Hartl K, Kaszowska M, Kumar Y, Wahl B, Paprotka T, Nagy E, Lukasiewicz J, Lukasiewicz J, Nagy G, Szijártó V. 2017. Discovery of monoclonal antibodies cross-reactive to novel subserotypes of $K$. pneumoniae. Sci Rep 7: 1-13. DOI: 10.1038/s41598-017-06682-2.

He Y, Guo X, Xiang S, Li J, Li X, Xiang H, Chen D, Chen J. 2016 Comparative analyses of phenotypic methods and 16S rRNA, khe, $r р о B$ genes sequencing for identification of clinical isolates of Klebsiella pneumoniae. Antonie van Leeuwenhoek 109: 1029-1040.

Hellman J, Zanzot EM, Loiselle PM, Amato SF, Black KM, Ge Y, Kurnick JT, Warren HS. 1997. Antiserum against Escherichia coli J5 contains antibodies reactive with outer membrane proteins of heterologous gram-negative bacteria. J Infect Dis 176: 1260-1268. DOI: $10.1086 / 514121$.

Hober S, Nord K, Linhult M. 2007. Protein A chromatography for antibody purification. J Chromatograph B 848: 40-47. DOI: 10.1016/j.jchromb.2006.09.030.

Hornbeck, P. 2017. Double-immunodiffusion assay for detecting specific antibodies (Ouchterlony). Curr. Protoc. Immunol. 116:2.3.1-2.3.4. DOI: $10.1002 /$ cpim. 18

Jang S, Wheeler L, Carey RB, Jensen B, Crandall CM, Schrader KN, Jessup DC, Kathleen G, Frances MD. 2010. Pleuritis and suppurative pneumonia associated with a hypermucoviscosity phenotype of Klebsiella pneumoniae in California sea lions (Zalophus californianus). Vet Microbiol 141 (1-2): 174-177. DOI: 10.1016/j.vetmic.2009.07.032.

Jun JB. 2018. Klebsiella pneumoniae liver abscess. Infect Chemother 50: 210-218. DOI: 10.3947/ic.2018.50.3.210.

Li L, Yu T, Ma Y, Yang Z, Wang W, Song X, She Y, Guo T, Kong J, Wang M, Xu H. 2019. The genetic structures of an extensively drugresistant (XDR) Klebsiella pneumoniae and its plasmids. Front Cell Infect Microbiol 9: 1-11. DOI: 10.3389/fcimb.2018.00446.

Lin ZW, Zheng JX, Bai B, Xu GJ, Lin FJ, Chen Z, Sun X, Qu D, Yu ZJ, Deng QW. 2020. Characteristics of hypervirulent Klebsiella pneumoniae: Does low expression of rmpA contribute to the absence of hypervirulence? Front Microbiol 11: 1-11. DOI: 10.3389/fmicb.2020.00436.

Liu S, Li S, Zhang Y, Wang Y, Zhu Y, Wang B, Chen ZN. 2017. Purification of a polyclonal antibody against CD147 for ELISA using antigen-immunoaffinity chromatography. Mol Med Rep 15: 40354040. DOI: 10.3892/mmr.2017.6523.

M'lan-Britoh A, Meité S, Boni C, Zaba F, Koffi KS, Guessennd N, Kakou NS, Faye- Kette H. Dosso M. 2017. First molecular investigation of capsular serotyping and hypervirulent (hvlp) of $K$. pneumoniae in University Hospital Center of Yopougon Cote D'Ivoire. Afr J Clin Exp Microbiol 19: 70-75.

Majidi, Amirkhiz. 2007. Production and purification of polyclonal antibody against bovine immunoglobulins in rabbits. Afr J Biotechnol 6: 1369-1372. DOI: 10.4314/ajcemv19i1.10. 
Martin RM, Bachman MA. 2018. Colonization, infection, and the accessory genome of Klebsiella pneumoniae. front. Cell Infect Microbiol 8: 1-15. DOI: 10.3389/fcimb.2018.00004.

Matsumoto H, Haniu H, Komori N. 2019. Determination of Protein Molecular Weights on SDS-PAGE. In: Kurien BT, Scofield RH (eds) Methods in Molecular Biology. Humana Press Inc, New York.

Nandin IS, Fong C, Deantonio C, Torreno-Pina JA, Pecetta S, Maldonado P, Gasparrini F, Ordovas-Montanes J, Kazer SW, Kjaer, Svend, Borley DW, Nair U, Coleman JA, Lingwood D, Shalek AK, Meffre E, Poignard P, Burton DR, Batista FD. 2017. Novel in vitro booster vaccination to rapidly generate antigen-specific human monoclonal antibodies. J Exp Med 214: 2471-2490. DOI: 10.1084/jem.20170633.

Nutt SL, Hodgkin PD, Tarlinton DM, Corcoran LM. 2015. The generation of antibody-secreting plasma cells. Nat Rev Immunol 15: 160-171. DOI: $10.1038 /$ nri3795.

Opoku-Temeng C, Kobayashi SD, DeLeo FR. 2019. Klebsiella pneumoniae capsule polysaccharide as a target for therapeutics and vaccines. J Comput Struct Biotechnol 17: 1360-1366. DOI: 10.1016/j.csbj.2019.09.011.

Parija S, Biswas R. 2011. A rapid slide agglutination test for the diagnosis of neurocysticercosis in the rural health set up. Trop Parasitol 1: 94 98. DOI: $10.4103 / 2229-5070.86942$.

Patterson K, Olsen B, Thomas, C, Norn D, Tam M, Elkins C. 2002. Development of a rapid immunodiagnostic test for Haemophilus ducreyi. J Clin Microbiol 40: 3694-3702. DOI 10.1128/JCM.40.10.3694-3702.2002.

Pohanka M. 2009. Monoclonal and polyclonal antibodies production preparation of potent biorecognition element. J Appl Biomed 7: 115121

Priyanka A, Akshatha K, Deekshit VK, Prarthana J, Akhila DS. 2020 Klebsiella pneumoniae infections and antimicrobial drug resistance. In: Sidharda B, Dyavaiah, M, Syed A (eds) Model organisms for microbial pathogenesis, biofilm formation and antimicrobial drug discovery. Springer, Singapore.

Remya P, Shanthi M, Sekar U. 2019. Characterisation of virulence genes associated with pathogenicity in Klebsiella pneumoniae. Indian J Med Microbiol 37: 210-218. DOI: 10.4103/ijmm.IJMM_19_157.

Ribeiro MG, Motta RG, Paes AC, Allendorf SD, Salerno T, Siqueira AK, Fernandes MC, Lara GHB. 2008. Peracute bovine mastitis caused by Klebsiella pneumoniae. Arquivo Brasileiro de Medicina Veterinaria Zootecnia 60: 485-488. DOI: 10.1590/S0102-09352008000200031.

Rodrigo G, Gruvegård M, Van Alstine J. 2015. Antibody fragments and their purification by protein 1 affinity chromatography. Antibodies 4: 259-277. DOI: 10.3390/antib4030259.

Sadeghi S, Aghebati-Maleki L, Nozari S, Majidi J. 2018. A methodological approach for production and purification of polyclonal antibody against dog IgG. Vet Res Forum 9: 13-18.

Sallusto F, Lanzavecchia A, Araki K, Ahmed R. 2010. From vaccines to memory and back. Immunity 33: 451-463. DOI 10.1016/j.immuni.2010.10.008
Sarba EJ, Kudama K, Dandecha M, Megersa L, Borena BM, Gebremdhin EZ. 2020. Prevalence, organ distribution and antimicrobial susceptibility profile of Salmonella isolated from chickens purchased from markets in selected districts of West Shoa, Ethiopia. Ethiopian Vet J 24: 73-89. DOI: $10.4314 /$ evjv24i2.5.

Schroeder Jr HW, Cavacini L. 2010. Structure and function of immunoglobulins. J Allergy Clin Immunol 125: S41-S52. DOI: 10.1016/j.jaci.2009.09.046.

Seo R. Kudo D, Gu Y, Yano H, Aoyagi T, Omura T, Irino S, Kaku M, Kushimoto S. 2016. Invasive liver abscess syndrome caused by Klebsiella pneumoniae with definite K2 serotyping in Japan: A case report. Surg Case Rep 2: 1-5. DOI: 10.1186/s40792-016-0201-2. doi:10.1186/s40792-016-0201-2.

Siu LK, Yeh KM, Lin JC, Fung CP, Chang FY. 2012. Klebsiella pneumoniae liver abscess: a new invasive syndrome. Lancet Infect Dis 12: 881-887.

Snider GL. 2000. Clinical Relevance Summary. Chest 117: 244S-246S. DOI: $10.1378 /$ chest1175suppl_1.244s.

Sorden SD, Harms PA, Nawagitgul P, Cavanaugh D, Paul PS. 1999. Development of a polyclonal-antibody-based immunohistochemical method for the detection of type 2 porcine circovirus in formalinfixed, paraffin-embedded tissue. J Vet Diagn Investig 11: 528-530. DOI: $10.1177 / 104063879901100607$

Talib N, Salam F, Sulaiman Y. 2018. Development of polyclonal antibody against clenbuterol for immunoassay application. Molecules 23: 789. DOI: $10.3390 /$ molecules23040789.

Weber J, Peng H, Rader C. 2017. From rabbit antibody repertoires to rabbit monoclonal antibodies. Exp Mol Med 49: 1-12. DOI: 10.1038/emm.2017.23

Whitton JL, Slifka MK, Liu F, Nussbaum AK, Whitmire JK. 2004. The Regulation and Maturation of Antiviral Immune Responses. Adv Virus Res 63: 181-238. DOI: 10.1016/S0065-3527(04)63003-X.

Wingfield P. 1998. Protein Precipitation Using Ammonium Sulfate. Curr Protoc Protein Sci 3: 1-10. DOI: 10.1002/0471140864.psa03fs13.

Yeh KM, Kurup A, Siu LK, Koh YL, Fung CP, Lin JC, Chen TL, Chang FY, Koh TH. 2007. Capsular serotype K1 or K2, rather than magA and rmpA, is a major virulence determinant for Klebsiella pneumoniae liver abscess in Singapore and Taiwan. J Clin Microbiol 45: 466-471. DOI: 10.1128/JCM.01150-06.

Zhang W, Liu G, Tang F, Shao J, Lu Y, Bao Y, Yao H, Lu C. 2011. Preabsorbed immunoproteomics: A novel method for the detection of Streptococcus suis surface proteins. PLoS ONE. 6: 1-7. DOI: 10.1371/journal.pone.0021234.

Zhang WD, Wang WH, Jia S. 2015. Distribution of immunoglobulin G antibody secretory cells in small intestine of Bactrian camels (Camelus bactrianus). BMC Vete Res 11: 2-8. DOI: 10.1186/s12917015-0538-Y.

Zhou ZH, Zhang Y, Hu YF, Wahl LM, Cisar JO, Notkins AL. 2007. The broad antibacterial activity of the natural antibody repertoire is due to polyreactive antibodies. Cell Host Microbe 1: 51-61. DOI: 10.1016/j.chom.2007.01.002. 